Gut, 1970, 11, 62-68

\title{
Relationship between pancreatic secretion and pancreatic blood flow
}

\author{
BERNARD GOODHEAD, ${ }^{1}$ HARRY S. HIMAL, AND JOSEPH ZANBILOWICZ \\ From the Department of Surgery, Royal Victoria Hospital and McGill University, Montreal, Quebec, \\ Canada
}

SUMMARY An indicator fractionation technique using radioactive rubidium has been used to measure pancreatic blood flow after infusions of secretin, pancreozymin, urecholine, and pentagastrin.

Secretin resulted in the production of a large volume of low viscous pancreatic juice and was associated with an increase in the cardiac output. Duodenal and pancreatic blood flow and perfusion rate were increased significantly. Blood flow to the remainder of the gastrointestinal organs was only marginally increased but the perfusion rate in each organ was increased significantly.

Infusion of pancreozymin, urecholine, and pentagastrin resulted in the output of a small volume of viscous juice and was associated with no increase in cardiac output but with an increase in both pancreatic blood flow and perfusion rate.

The blood supply to glandular organs is usually increased during secretion (Jacobson, 1967), and this phenomenon has been studied in considerable detail in the salivary glands (Burgen and Emmelin, 1961; Lewis, 1967) and in the stomach (Delaney and Grim, 1965; Jacobson, Swan, and Grossman, 1967), and although it is many years ago that Claude Bernard (1856) made observations that suggested an increase also in blood flow through the pancreas during digestion few studies have been made. In a review of the subject Tankel and Hollander (1957) concluded, from the evidence then available, that there were insufficient data to establish any association between pancreatic secretion and an increase in blood flow to the gland.

${ }^{1}$ Address for correspondence: B. Goodhead, Department of Surgery, The University of Texas, Medical School at San Antonio, 7703 Floyd Curl Drive, San Antonio, Texas 78229, U.S.A.
More recent studies on this subject, however, point strongly to an association between pancreatic secretion and increased blood flow. Kuznetsova (1963), using a thermostrumuhr on the pancreatic artery, found an increased blood flow in conscious dogs after feeding meat, bread, or milk and also after the infusion of secretin. Eichelter and Schenk (1966), measuring blood flow with an electromagnetic flow probe on the superior pancreatico-duodenal artery, also found an increase in blood flow after the pancreas had been stimulated with secretin. Holton and Jones (1960), using a photocell method to detect qualitative changes in the opacity of a transilluminated portion of the pancreas in cats, found an increase in blood flow to the organ associated with the infusion of both secretin and pancreozymin. Delaney and Grim (1966), using the indicator fractionation technique 
demonstrated an increase in pancreatic blood flow after the infusion of secretin but not after the infusion of pancreozymin. They did not, however, include any measurements of pancreatic secretion in these studies.

The present investigations were designed to study the quantitative effects of secretin, pancreozymin, urecholine, and pentagastrin on pancreatic secretion, and to correlate the results with any changes in pancreatic blood flow. An indicator fractionation technique using radioactive rubidium $\left({ }^{86} \mathrm{Rb}\right)$ was used to measure blood flow.

\section{Materials and Methods}

Thirty-one healthy mongrel dogs weighing 12 to $17 \mathrm{~kg}$ were used. After fasting for 24 hours, anaesthesia was induced with sodium pentobarbital $(25 \mathrm{mg} / \mathrm{kg})$ and each dog was intubated and artificially ventilated to maintain the arterial $\mathrm{pCO}_{2}$ and $\mathrm{pO}_{2}$ within normal limits. The $p \mathrm{H}$, $\mathrm{pCO}_{2}$, and $\mathrm{pO}_{2}$ were measured using an $\mathrm{IL}^{1}$ micro $\mathrm{pH}$ and gas analysing system.

The abdomen was opened through a right subcostal incision and the duodenum was exposed. The pylorus was tied with a silk ligature to prevent gastric juice entering the duodenum. The larger of the two pancreatic ducts was identified, at its entrance into the duodenal wall, and cannulated with no. 120 polyethylene tubing to collect pancreatic secretion. No attempt was made to identify the smaller of the two pancreatic ducts, and handling the duodenum and pancreas was kept to an absolute minimum. The abdomen was then closed in layers and the polyethylene tube brought out through the most dependent portion of the wound. At the end of this procedure, each dog was given $7.5 \mathrm{ml}$ normal saline per kilogram body weight intravenously.

Fasting pancreatic secretion was collected for 90 minutes, and, at the conclusion of this control period, each dog was allocated at random to one of the following experimental groups:

\section{GROUP 1: SIX CONTROL DOGS}

Ten $\mathrm{ml}$ of normal saline was infused intravenously for two minutes. Eight minutes later, a bolus of ${ }^{86} \mathrm{Rb}$ was injected into the right atrium to determine the cardiac output. The animal was killed two minutes later. Pancreatic secretion was collected during the latter 10-minute period.

GROUP 2: SEVEN SECRETIN DOGS ${ }^{2}$

Five units of secretin per kilogram body weight in $10 \mathrm{ml}$ normal saline was infused intravenously

'Instrumentation Laboratory Inc., model 113-S2.

${ }^{2}$ Boots Pure Drug Co. Ltd., Nottingham, England over a period of two minutes. Eight minutes later, a bolus of ${ }^{86} \mathrm{Rb}$ was injected into the right atrium to determine the cardiac output. The animal was killed two minutes later. Pancreatic secretion was collected during the latter 10-minute period.

GROUP 3: SIX PANCREOZYMIN DOGS ${ }^{3}$ Identical studies to those of group 2 were made after infusing 2 units of pancreozymin per kilogram of body weight in $10 \mathrm{ml}$ normal saline.

GROUP 4: SIX URECHOLINE DOGS ${ }^{4}$ Identical studies to those of group 2 were made after infusing $4 \mathrm{mg}$ urecholine in $10 \mathrm{ml}$ normal saline.

GROUP 5: SIX PENTAGASTRIN DOGS ${ }^{5}$

Identical studies to those of group 2 were made during the infusion of $0.2 \mu \mathrm{g}$ pentagastrin per kilogram body weight per minute continuously intravenously.

In groups 1 and 2 , in addition to pancreatic blood flow, blood flow to the oesophagus, stomach, duodenum, gallbladder, jejunum, ileum, and colon was measured also.

Blood flow to each organ was measured by the radioactive rubidium fractionation technique, the principle of which was first described by Sapirstein (1958). The femoral artery and vein were exposed in one groin and cannulated with polyethylene tubing. The cannulae were passed until the tips lay in the lower abdominal aorta and in the inferior vena cava near the right atrium respectively. Ten minutes before the injection of rubidium, anticoagulation of each dog was achieved with $4 \mathrm{mg} / \mathrm{kg}$ of heparin given intravenously. At the selected moment, $1 \mathrm{ml}$ of ${ }^{86} \mathrm{Rb}$ $(40-80 \mu \mathrm{c})$ was injected into the venous cannula and then 'shot' into the right atrium by rapidly injecting $20 \mathrm{ml}$ normal saline. Simultaneous blood samples were collected from the abdominal aorta, at the rate of two per second for 15 seconds, for the determination of the cardiac output. The total volume of blood removed from each dog never exceeded $20 \mathrm{ml}$. Two minutes after the ${ }^{86} \mathrm{Rb}$ injection, each animal was killed by a rapid intracardiac injection of $50 \mathrm{ml}$ saturated potassium chloride solution. The pancreas and other organs under study were removed, blotted dry, and weighed. After digestion in concentrated fuming nitric acid, the volume was measured and the radioactivity of an aliquot determined.

The radioactivity of aliquots of the aortic blood samples was measured and the cardiac output was calculated from the resultant isotope dilution curve by using the conventional Stewart- 
Hamilton equation. Organ blood flow was calculated using the method suggested by Delaney and Grim (1965), in which the radioactivity of each organ is divided by the area under the arterial isotope dilution curve.

Counts of radioactivity were done using an automatic well scintillation counter, and statistical analyses of the results using the standard Student $t$ test for independent variates and also the Mann-Whitney non-parametric test.

\section{VALIDATION EXPERIMENTS}

In addition to determining cardiac output, in three control and in three dogs infused with secretin, an isotope dilution curve was obtained by the simultaneous collection of blood from the aorta and superior pancreatic-duodenal vein following an injection of ${ }^{86} \mathrm{Rb}$ into the right atrium. Blood samples were taken at 15 -second intervals for three minutes, and the radioactivity of each sample was measured.

\section{Results}

The mean body weight was $15 \cdot 0 \mathrm{~kg}$ and did not differ significantly between groups. Although the pancreatic weight was raised in groups $2,3,4$, and 5 , it was only significantly raised in group 3 $(P<0.05)$. In the control dogs the mean cardiac output was $182 \mathrm{ml} / \mathrm{min} / \mathrm{kg}$, and the pancreatic blood flow was $15.6 \mathrm{ml} / \mathrm{min}$ (or $0.55 \%$ of the cardiac output) with a perfusion rate of 57.0 $\mathrm{ml} / \mathrm{min} / 100 \mathrm{~g}$ (Tables I and II and Figs. 1 and 2). Basal pancreatic secretion was low, with an average of $0.012 \mathrm{ml} / \mathrm{min}$.

\begin{tabular}{|c|c|c|c|c|c|}
\hline Group & $\begin{array}{l}\text { No. of } \\
\text { Dogs }\end{array}$ & $\begin{array}{l}\text { Body } \\
\text { Weight }(k g)\end{array}$ & $\begin{array}{l}\text { Pancreatic } \\
\text { Weight }(g / k g)\end{array}$ & $\begin{array}{l}\text { Cardiac } \\
\text { Output } \\
(\mathrm{ml} / \mathrm{min} / \mathrm{kg})\end{array}$ & $\begin{array}{l}\text { Volume } \\
\text { Pancreatic } \\
\text { Secretion after } \\
\text { Stimulation } \\
\text { (ml/min) }\end{array}$ \\
\hline $\begin{array}{ll}1 & \text { Control } \\
2 & \text { Secretin } \\
3 & \text { Pancreozymin } \\
4 & \text { Urecholine } \\
5 & \text { Pentagastrin }\end{array}$ & $\begin{array}{l}6 \\
7 \\
6 \\
6 \\
6\end{array}$ & $\begin{array}{l}14 \cdot 7 \\
12 \cdot 7 \\
15 \cdot 9 \\
16 \cdot 1 \\
15 \cdot 8\end{array}$ & $\begin{array}{l}1.85 \pm 0.19^{1} \\
2.12 \pm 0.32 \\
2.40 \pm 0.42 \\
2.09 \pm 0.37 \\
2.23 \pm 0.46\end{array}$ & $\begin{array}{l}182 \pm 251 \\
240 \pm 44 \\
202 \pm 31 \\
199 \pm 37 \\
153 \pm 36\end{array}$ & $\begin{array}{l}0.012 \pm 0.003 \\
0.465 \pm 0.207 \\
0.036 \pm 0.013 \\
0.041 \pm 0.002 \\
0.103 \pm 0.041\end{array}$ \\
\hline
\end{tabular}

Table I Mean values for body weight, pancreatic weight, cardiac output, and pancreatic secretion in the five experimental groups

${ }^{1}$ Standard deviation.

\begin{tabular}{|c|c|c|c|c|}
\hline \multirow[t]{2}{*}{ Group } & \multirow{2}{*}{$\begin{array}{l}\text { No. of } \\
\text { Dogs }\end{array}$} & \multicolumn{2}{|c|}{ Pancreatic Blood Flow } & \multirow[b]{2}{*}{$\begin{array}{l}\text { Percentage of } \\
\text { Cardiac Output }\end{array}$} \\
\hline & & $m l / \min$ & $\mathrm{ml} / \mathrm{min} / 100 \mathrm{~g}$ & \\
\hline $\begin{array}{ll}1 & \text { Control } \\
2 & \text { Secretin } \\
3 & \text { Panereozymin } \\
4 & \text { Urecholine } \\
5 & \text { Pentagastrin }\end{array}$ & $\begin{array}{l}6 \\
7 \\
6 \\
6 \\
6\end{array}$ & $\begin{array}{l}15 \cdot 6 \pm 6 \cdot 7^{1} \\
45 \cdot 8 \pm 22 \cdot 7 \\
46 \cdot 4 \pm 13 \cdot 4 \\
42 \cdot 8 \pm 9 \cdot 3 \\
35 \cdot 4 \pm 11 \cdot 5\end{array}$ & $\begin{array}{r}57.0 \pm 23 \cdot 11 \\
164.2 \pm 30.3 \\
124.2 \pm 37.8 \\
130.4 \pm 35.0 \\
102.9 \pm 29.8\end{array}$ & $\begin{array}{l}0.55 \pm 0.14^{1} \\
1.48 \pm 0.33 \\
1.45 \pm 0.36 \\
1.34 \pm 0.28 \\
1.54 \pm 0.52\end{array}$ \\
\hline
\end{tabular}

Table II Mean values for pancreatic blood flow in the five experimental groups

'Standard deviation.

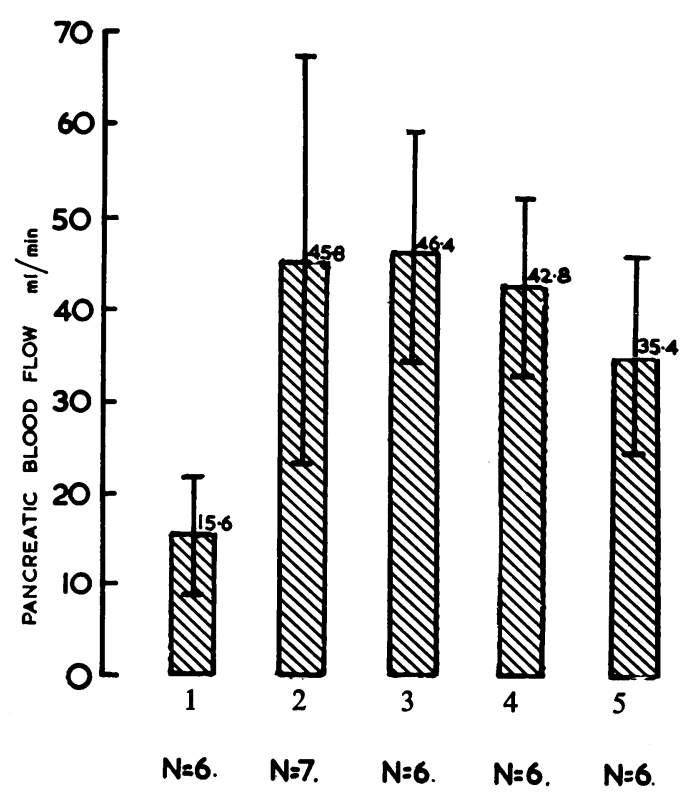

Fig. 1 Mean pancreatic blood flow $(\mathrm{ml} / \mathrm{min} \pm S D)$ in the five experimental groups.

1 = control; 2 = secretion; 3 = pancreozymin;

$4=$ urecholine; $5=$ pentagastrin.

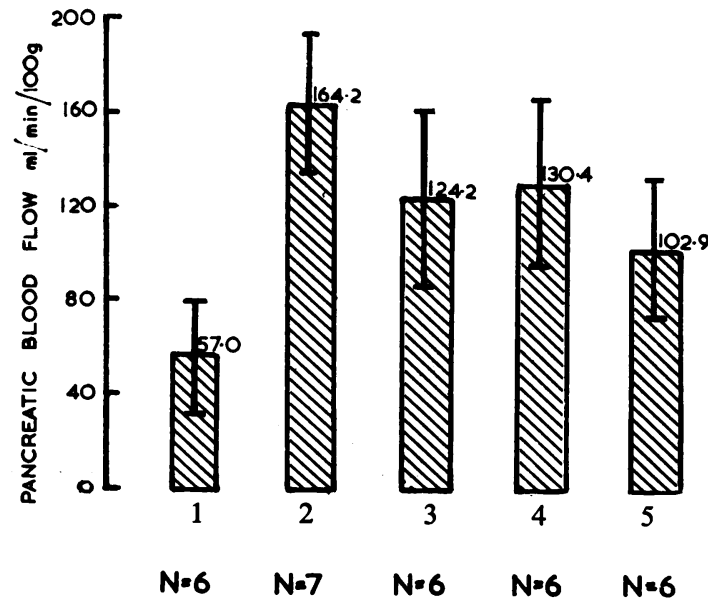

Fig. 2 Mean pancreatic perfusion rate $(\mathrm{ml} / \mathrm{min} /$ $100 \mathrm{~g} \pm S D$ ) in the five experimental groups.

$1=$ control; 2 = secretion; 3 = pancreozymin;

$4=$ urecholine; $5=$ pentagastrin. 


\begin{tabular}{|c|c|c|c|c|c|c|c|c|c|c|c|}
\hline \multirow[t]{3}{*}{ Organ } & \multirow{3}{*}{$\begin{array}{l}\text { Experimental } \\
\text { Group }\end{array}$} & \multirow{3}{*}{$\begin{array}{l}\text { No. of } \\
\text { Dogs }\end{array}$} & \multicolumn{9}{|c|}{ Organ Blood Flow } \\
\hline & & & \multicolumn{3}{|l|}{$m l / \min$} & \multicolumn{3}{|c|}{$\mathrm{ml} / \mathrm{min} / 100 \mathrm{~g}$} & \multicolumn{3}{|c|}{$\begin{array}{l}\text { Percentage of Cardiac } \\
\text { Output }\end{array}$} \\
\hline & & & Mean & $\pm S D$ & $\mathbf{P}$ & Mean & $\pm S D$ & $\mathbf{P}$ & Mean & $\pm S D$ & $\mathbf{P}$ \\
\hline \multirow[t]{2}{*}{ Oesophagus } & Control & 6 & 1.9 & $0 \cdot 7$ & \multirow{2}{*}{-} & $18 \cdot 5$ & $5 \cdot 2$ & \multirow{2}{*}{+1} & 0.07 & 0.02 & \multirow{2}{*}{-} \\
\hline & Secretin & 7 & $2 \cdot 7$ & $1 \cdot 3$ & & $36 \cdot 6$ & $15 \cdot 3$ & & $0 \cdot 10$ & 0.06 & \\
\hline \multirow[t]{2}{*}{ Stomach } & Control & 6 & $57 \cdot 3$ & $6 \cdot 6$ & \multirow{2}{*}{-} & $42 \cdot 2$ & $8 \cdot 3$ & \multirow{2}{*}{+} & $2 \cdot 30$ & 0.63 & \multirow{2}{*}{-} \\
\hline & Secretin & 7 & $76 \cdot 9$ & 24.9 & & $72 \cdot 0$ & $13 \cdot 5$ & & $2 \cdot 63$ & $0 \cdot 77$ & \\
\hline \multirow[t]{2}{*}{ Duodenum } & Control & 6 & $42 \cdot 2$ & 13.4 & \multirow{2}{*}{$+^{1}$} & $102 \cdot 5$ & $10 \cdot 6$ & \multirow{2}{*}{+} & $1 \cdot 60$ & 0.23 & \multirow{2}{*}{+} \\
\hline & Secretin & 7 & $76 \cdot 0$ & $24 \cdot 4$ & & $193 \cdot 1$ & $38 \cdot 1$ & & $2 \cdot 55$ & 0.55 & \\
\hline \multirow[t]{2}{*}{ Gall bladder } & Control & 6 & 0.8 & $0 \cdot 1$ & \multirow{2}{*}{-} & $36 \cdot 6$ & $10 \cdot 2$ & \multirow{2}{*}{+} & 0.29 & 0.02 & \multirow{2}{*}{ - } \\
\hline & Secretin & 7 & $1 \cdot 1$ & $0 \cdot 5$ & & $63 \cdot 2$ & $17 \cdot 1$ & & 0.36 & $0 \cdot 17$ & \\
\hline \multirow[t]{2}{*}{ Pancreas } & Control & 6 & $15 \cdot 6$ & $6 \cdot 7$ & \multirow{2}{*}{+} & $57 \cdot 0$ & $23 \cdot 1$ & \multirow{2}{*}{+} & 0.55 & $0 \cdot 14$ & \multirow{2}{*}{+} \\
\hline & Secretin & 7 & $45 \cdot 8$ & $22 \cdot 7$ & & $164 \cdot 2$ & $20 \cdot 3$ & & 1.48 & 0.33 & \\
\hline \multirow[t]{2}{*}{ Jejunum and ileum } & Control & 6 & $274 \cdot 3$ & $140 \cdot 0$ & \multirow{2}{*}{ - } & $90 \cdot 1$ & $36 \cdot 2$ & \multirow{2}{*}{+} & $9 \cdot 59$ & $3 \cdot 73$ & \multirow{2}{*}{ - } \\
\hline & Secretin & 7 & 341.8 & $114 \cdot 9$ & & $152 \cdot 2$ & $16 \cdot 9$ & & $11 \cdot 36$ & $1 \cdot 59$ & \\
\hline \multirow[t]{2}{*}{ Colon } & Control & 6 & $46 \cdot 9$ & $9 \cdot 6$ & \multirow{2}{*}{-} & $93 \cdot 0$ & 4.4 & \multirow{2}{*}{+} & $1 \cdot 77$ & 0.37 & \multirow{2}{*}{ - } \\
\hline & Secretin & 7 & $57 \cdot 8$ & $30 \cdot 0$ & & $141 \cdot 3$ & 33.9 & & $1 \cdot 88$ & 0.56 & \\
\hline
\end{tabular}

Table III Mean values for organ blood flow in experimental groups 1 (control) and 2 (secretin)

'Significantly different from control $(P<0.05)$.

The infusion of secretin had a marked stimulatory effect on pancreat:c secretion and the mean secretory rate increased to $0.465 \mathrm{ml} / \mathrm{min}$. In this group, the mean cardiac output was raised to $240 \mathrm{ml} / \mathrm{min} / \mathrm{kg}$, a significant rise $(P<0.05)$. During the infusion of secretin, although the systolic blood pressure remained unchanged, diastolic pressure fell slightly with a resultant increase in the pulse pressure. The pancreatic blood flow following infusion increased markedly to $45.8 \mathrm{ml} / \mathrm{min}$ (or $1.48 \%$ of the cardiac output) and the pancreatic perfusion rate increased to $164.2 \mathrm{ml} / \mathrm{min} / 100 \mathrm{~g}(\mathrm{P}<0.05)$.

The infusion of pancreozymin, urecholine, and pentagastrin all resulted in an increase in pancreatic secretion to $0.036,0.041$, and 0.103 $\mathrm{ml} / \mathrm{min}$ respectively. In each group, however, the rate of secretion was significantly less than the rate following the infusion of secretin $(P<0.05)$. The mean cardiac output in groups 3,4 , and 5 did not differ significantly from that in the control group (group 1). The pancreatic blood flow was increased by pancreozymin to $46.4 \mathrm{ml} / \mathrm{min}$ (or $1.45 \%$ of the cardiac output), by urecholine to $42.8 \mathrm{ml} / \mathrm{min}$ (or $1.34 \%$ of the cardiac output), and by pentagastrin to $35.4 \mathrm{ml} / \mathrm{min}$ (or $1.54 \%$ of the cardiac output). The pancreatic perfusion rate was similarly increased to $124 \cdot 2,130 \cdot 4$, and $102.9 \mathrm{ml} / \mathrm{min} / 100 \mathrm{~g}$ respectively. These blood flow values are all significantly raised when compared with the control group $(P<0.05)$. Comparison of blood flow changes between groups 2 , 3,4 , and 5 showed that the only significant difference was between the perfusion rate in the secretin and pentagastrin groups.

\section{GASTROINTESTINAL BLOOD FLOW}

Secretin resulted in an increase in both total blood flow and perfusion rate to each organ (Table III). The increase in blood flow was marginal except in the duodenum and pancreas where the increase was significant $(P<0.05)$. In comparison, the perfusion rate in each organ was significantly elevated $(P<0.05)$.

\section{VALIDATION EXPERIMENTS}

Extraction ratios for the organs drained by the superior pancreatico-duodenal vein were calculated by dividing the difference in areas under the observed arterial and venous curves by the area under the extrapolated arterial curve. These ratios varied between 0.93 and 1.07. Similar extraction ratios were found after the infusion of secretin.

\section{Discussion}

The indicator fractionation technique for measuring blood flow assumes that the fraction of the injected isotope in an organ shortly after the injection of a small bolus into the right atrium is equal to the fraction of the cardiac output 
perfusing that organ. Rubidium behaves physiologically like potassium and permeates cell membranes freely (Burch, Threefoot, and Ray, 1955; Tyor and Eldridge, 1956). The time course of radioactivity in aortic and pancreatic venous blood following an injection of a bolus of ${ }^{86} \mathrm{Rb}$ was similar in both the control and in the dogs infused with secretin. Extraction ratios in both these groups were similar indicating that secretin had no specific effect on the uptake of rubidium by the pancreas. The extraction ratios, which varied between 0.93 and 1.07 , indicate that the amount of isotope in the organs drained by the superior pancreatico-duodenal vein deviated no more than plus or minus $7 \%$ from the amount that these structures would contain under ideal circumstances, that is, complete extraction of the isotope by the tissues of the body during one capillary passage. The accuracy of the indicator fractionation technique compares, therefore, most favourably with alternative methods for measuring blood flow.

In the present studies, the mean values obtained for pancreatic blood flow in the control dogs agree favourably with the findings of Delaney and Grim (1966), Papp, Makara, Hajtman, and Csáki (1966), and Gilsdorf, Peter, Pearl, and Leonard (1965) who used a similar method for measuring blood flow. These values compare closely also with those obtained by BurtonOpitz (1912) and by Bennett and Still (1933) who measured blood flow with a stromuhr on the superior pancreatico-duodenal artery and vein respectively.

Secretin had a marked stimulatory effect on the cardiac output and pancreatic blood flow. Both blood flow and perfusion rate were increased to a comparable degree. This finding contrasts with the report of Delaney and Grim (1966) who found that although secretin resulted in a greatly increased pancreatic perfusion rate, the blood flow was only marginally increased. An increase in pancreatic blood flow by secretin was noted also by Eichelter and Schenk (1966) who measured blood flow by an electromagnetic flow probe on the superior pancreatico-duodenal artery. Other investigators who have noted an increased pancreatic blood flow after the infusion of secretin include Holton and Jones (1960), Gayet and Guillaume (1930a and b), and Malteos and Watson (1939).

On the other hand, Weaver (1928) collected the venous outflow from the pancreas and found no increase in response to secretin. Bennett and Still (1933) reported similar observations and suggested that an increase in pancreatic duct pressure could result in an increased rate of blood flow through the gland. This observation has never been confirmed. Recent work by Barlow, Greenwell, Harper, and Scratcherd (1968) has demonstrated that a single injection of secretin results in an increase in pancreatic blood flow whereas subsequent injections, although stimulat- ing secretion, usually had less or no effect on blood flow. These findings contrast with the effect of repeated injections of pancreozymin which resulted consistently in an increased blood flow.

A detailed study of the relationship of pancreatic blood flow and secretion in conscious dogs has been reported recently by Kuznetsova (1963) who prepared dogs with a thermostrumuhr implanted on the superior pancreatico-duodenal artery and with an external pancreatic fistula. Although measurements of blood flow were only qualitative, Kuznetsova demonstrated that blood flow to the gland was increased following duodenal acidification and after feeding meat, milk, or bread. Exogenous secretin was found to affect blood flow only slightly and then irregularly.

The preparation of secretin used in the present study was not pure and it is well documented that commercial secretin contains small quantities of pancreozymin, cholecystokinin, enterosin, and serotonin (Anderson, 1966). However, all these substances are in very low concentration and it seems unlikely that the significant increase in blood flow demonstrated following infusion of secretin could be accounted for solely by the presence of these impurities. Secretin itself must be assumed to have vasoactive properties.

Eichelter and Schenk (1966), as well as demonstrating an increase in pancreatic blood flow, also noted a decrease in blood flow in the infrarenal aorta during infusion of secretin. These investigators suggested that this finding might be explained by an increase in blood flow to the other gastrointestinal organs although no actual measurements were done. In the present study, measurements of blood flow to the other gastrointestinal organs were undertaken. Following infusion of secretin, blood flow to each organ was increased, but only significantly in the duodenum and pancreas. On the other hand, the perfusion rate was significantly increased in each organ. This finding is of interest, and, since there was no change in systolic blood pressure, it can only be explained by assuming that secretin lowered the vascular resistance in the organs studied.

The infusion of pancreozymin resulted also in a significant increase of pancreatic blood flow and perfusion rate which are findings in agreement with those of Holton and Jones (1960) and Barlow et al (1968). Delaney and Grim (1966), on the other hand, were unable to demonstrate any increase in blood flow or perfusion rate after pancreozymin. It is difficult to explain this discrepancy, but, since these investigators made no measurements of pancreatic secretion, it is conceivable that the preparation of pancreozymin they used was either not potent or the effect was over at the time when the blood flow was measured.

Although very small quantities of secretin were present as an impurity in the pancreozymin preparation used in this study (Crick, Harper, and Raper, 1950), it was found that this quantity was insufficient to stimulate the output of a large 
volume of low viscous pancreatic secretion. It was therefore present probably in insufficient quantities to account for the significant increase in blood flow.

The effect of other pancreatic stimulants on pancreatic blood flow has been studied. Gayet and Guillaume (1930a and b) found that vagal stimulation increased pancreatic blood flow, and Kuznetsova (1963), who studied the effect of sham feeding, also found an increase in blood flow. Anrep (1916), however, found no change in pancreatic blood flow in decerebrate animals after vagal stimulation, but his experimental preparation was unphysiological. Stimulation of the splanchnic nerves has been found by Anrep (1916), Gayet and Guillaume (1930b), and by Barlow et al (1968) to result in a decline in both pancreatic secretion and blood flow. Richins (1953) also studied the effect of sympathetic nerve stimulation. He found that stimulation of the cholinergic postganglionic sympatheticnervecomponents to the gland resulted in both an increase in the volume of the flow of blood and secretion in contrast to stimulation of the adrenergic components, which apparently resulted in a decreased volume of flow of blood and inhibition of pancreatic secretion. Electrical stimulation of either the anterior or posterior hypothalamus has been shown by Gilsdorf et al (1965) to result in an increase in both pancreatic secretion and pancreatic blood flow.

There is conflicting evidence concerning the effect of adrenaline. Babkin, Hebb, and Sergeyeva (1939) and Pfeffer and Hinton (1956) found that an injection of adrenaline resulted in an inhibition of pancreatic secretion and this effect was correlated by Delaney and Grim (1966) with a decrease in blood flow. Barlow et al (1968) made a detailed study of the effect of adrenaline and claim that there was a biphasic response. Following an injection, they demonstrated an initial decrease in blood flow which was followed after a few minutes by an increase. Pancreatic secretion was usually inhibited during the phase of decreased blood flow and enhanced in the succeeding phase.

Histamine increases the rate of secretion of secretin-stimulated juice (Brown, Harper, and Scratcherd, 1967) but not of resting juice (Holton and Jones (1960). Barlow et al (1968) found that histamine increased pancreatic blood flow although Delaney and Grim (1966) found the effect to be highly variable.

The literature contains no reference to the effects of urecholine or pentagastrin on pancreatic blood flow. In the present studies, both these synthetic secretagogues resulted in an increase in pancreatic blood flow and perfusion rate comparable to those found in the secretinand pancreozymin-stimulated gland.

In the absence of an experimentally demonstrable increase in pancreatic secretion, the relationship previously stated by some authors between pancreatic blood flow and secretion is unconvincing (Delaney and Grim, 1966). The present studies were designed deliberately, therefore, so that the pancreatic blood flow was not measured until an increase in the secretion rate had been demonstrated. Under these circumstances, infusions of each of the four pancreatic stimulants under investigation resulted in an increase in both the rate of secretion and of blood flow.

The factors responsible for the changes in blood flow associated with secretion are controversial. Bennett and Still (1933) and Tankel and Hoelander (1957) suggested that active secretion may result in an increase in intraductal pressure in the pancreas. The accompanying increase in tissue pressure resulted in an increase in blood flow by a nervous reflex. There is little evidence to support this hypothesis, and the alternative mechanism suggested by Hilton and Jones (1963) seems more plausible. Kallikrein, a potent vasodilator, is found in the pancreas and pancreatic juice, and Hilton and Jones (1963) have demonstrated that this substance may be released by vagal stimulation, acetylcholine, secretin, or pancreozymin. These investigators also demonstrated that initial stimulation with secretin resulted in a pancreatic juice rich in kinin-forming activity which progressively declined with subsequent injections. Repeated stimulation with pancreozymin, on the other hand, resulted in a persistently high concentration of a kinin-forming substance in the pancreatic juice. The different effects on blood flow of repeated injections of secretin and pancreozymin found by Barlow et al (1968) are now explicable.

The indicator fractionation technique used in this study for measuring blood flow has a number of advantages over alternative methods for measuring blood flow. For example, it involves little or no disturbance of the animal's normal physiology and it measures total functional blood flow to an organ. It can also provide information on blood flow to organs inaccessible to study by any other means, Its main disadvantage is that only one measurement can be obtained in each animal. It is not possible, therefore, to do initial control studies on each animal or to record phasic blood flow patterns or any fluctuations that may occur in mean blood flow. In addition, the duration of the vascular response and the phase of secretion at which it is initiated cannot be determined using this method. The relationship between an increased secretion rate and increase in pancreatic blood flow, however, is clearly demonstrated.

\section{References}

Anderson, M. C. (1966). In discussion of paper by Eichelter, P. and Schenk, W. R. Hemodynamics of pancreatic secretion (1966). Arch. Surg., 93, 200-207.

Anrep, G. V. (1916). The influence of the vagus on pancreatic secretion (Second communication). J. Physiol. (Lond.), 50, 421-433. 
Babkin, B. P., Hebb, C. O., and Sergeyeva, M. A. (1939). The parasympathetic-like effect of splanchnic nerve stimulation on pancreatic secretion. Quart. J. exp. Physiol., 29, 217237.

Barlow, T. E., Greenwell, J. R., Harper, A. A., and Scratcherd, T. (1968). Factors influencing pancreatic blood flow. In Blood Flow Through Organs and Tissues. Edited by Bain, W. H. and Harper, A. M., pp. 469-486. Livingstone, Edinburgh and London.

Bennett, A. L., and Still, E. U. (1933). A study of the relation of pancreatic duct pressure to the rate of blood flow through the pancreas. Amer. J. Physiol., 106, 454-459.

Bernard, C. (1856). Mémoire sur le pancréas. C.R. Acad. Sci., Paris, Suppl. 1, 379-563.

Brown, J. C., Harner, A. A., and Scratcherd, T. (1967). Potentiation of secretin stimulation of the pancreas. J. Physiol. (Lond.), 190, 519-530.

Burch, G. E., Threefoot, S. A., and Ray, C. T. (1955). The rate of disappearance of ${ }^{86} \mathrm{Rb}$ from the plasma, the biologic decay rates of ${ }^{80} \mathbf{R b}$, and the applicability of ${ }^{80} \mathbf{R b}$ as a tracer of potassium in man with and without chronic congestive heart failure. J. Lab. clin. Med., 45, 371-394.

Burgen, A. S. V., and Emmelin, N. (1961). Physiology of the Salivary Glands, pp. 121-139. Williams \& Wilkins, Baltimore.

Burton-Opitz, R. (1912). Uber die Strömung des Blutes in dem Gebiete der Pfortader. V. Die Blutversorgung des Pfortners und pankreas. Arch. Ges. Physiol., 146, 344-370.

Crick, J., Harper, A. A., and Raper, H. S. (1950). On the preparation of secretin and pancreozymin. J. Physiol. (Lond.), $110,367-376$.

Delaney, J. P., and Grim, E. (1965). Experimentally induced variations in canine gastric blood flow and its distribution. Amer. J. Physiol., 208, 353-358.

Delaney, J. P., and Grim, E. (1966). Influence of hormones and drugs on canine pancreatic blood flow. Amer. J. Physiol., 211, 1398-1402.

Eichelter, P., and Schenk, W. G., Jr. (1966). Hemodynamics of pancreatic secretion. Arch. Surg., 93, 200-207.

Gayet, R., and Guillaume, M. (1930a). Les réactions vasomotrices du pancréas etudiées par la mesure des débits sanguins. C.R. Soc. Biol. (Paris), 103, 1106-1110.

Gayet, R., and Guillaume, M. (1930b). Les relations quantitatives réciproques de la sécrétion due suc pancréatique et du débit sanguin. Compt. Rend. Soc. Biol., 103, 1216-1219.

Gilsdorf, R. B., Peter, E. T., Pearl, J. M., and Leonard, A. S. (1965). Hypothalamic influence on pancreatic blood flow and secretion. Surg. Forum, 16, 371-373.

Hilton, S. M., and Jones, M. (1963). Plasmin kinin and functional vasodilatation in the pancreas. J. Physiol. (Lond.), 165, 35-36P.

Holton, P., and Jones, M. (1960). Some observations on changes in the blood content of the cat's pancreas during activity. J. Physiol. (Lond.), 150, 479-486.

Jacobson, E. D. (1967). Secretion and blood flow in the gastrointestinal tract. In: Handbook of Physiology, Edited by Code, C. F. pp. 1043-062. Section 6, Volume 2. Alimentary Canal. The American Physiological Society, Washington, D.C.

Jacobson, E. D., Swan, K. G., and Grossman, M. I. (1967). Blood flow and secretion in the stomach. Gastroenterology, 52, 414-422.
Kuznetsova, E. K. (1963). Characteristics of blood supply of the pancreas during different phases of its activity. Fed. Proc. (Transl. Suppl.), 22, 99-104.

Lewis, G. P. (1967). The role of plasma kinins as mediator of functional vasodilation. Gastroenterology, 52, 406-413.

Maltesos, C., and Watson, R. H. (1939). Durchblutung und Sekretion des Pankreas bei humoraler Anregung. Arch. ges. Physiol., 241, 516-523.

Papp, M., Makara, G. B., Hajtman, B., and Csáki, L. (1966). A quantitative study of pancreatic blood flow in experiment pancreatitis. Gastroenterology, 51, 524-528.

Pfeffer, R. B., and Hinton, J. W. (1956). Some relationships between adrenal medullary and cortical substances and exocrine function of the pancreas in man. Gastroenterology, 31, 746-757.

Richins, C. A. (1953). Effect of sympathetic nerve stimulation on blood flow and secretion in the pancreas of the cat. Amer. J. Physiol., 173, 467-470.

Sapirstein, L. (1958). Regional blood flow by fractional distribution of indicators. Amer. J. Physiol., 193, 161-168.

Tankel, H. I., and Hollander, F. (1957). The relation between pancreatic secretion and local blood flow: a review. Gastroenterology, 32, 633-641.

Tyor, M. P., and Eldridge, J. S. (1956). A comparison of the metabolism of rubidium 86 and potassium 42 following simultaneous injection into man. Amer. J. Med. Sci., 232 186-193.

Weaver, M. M. (1928). Studies on the visceral vasomotor responses to intravenous injection of purified pancreatic secretion. Amer. J. Physiol., 85, 410-411. 